\title{
Relations between the State and the Chemical Industry in France, 176o-180o: The Case of Ceruse
}

\author{
Christine Lehman
}

The transformation of relations between the royal government and industry is an important feature of the history of the seventeenth and eighteenth centuries in France. Of course the state's influence on industrial development started long before the second half of the seventeenth century when it was reinforced by Colbert's reforms, which retained a significant influence during the eighteenth-century. ${ }^{1}$ For example, the new regulation issued on 26 January 1699 appointed the Académie des sciences, founded in 1666, to evaluate all new industrial machines: the principles of novelty and utility were reaffirmed and remained the indispensable conditions for obtaining a royal privilege.

Created in the sixteenth century in order to break the restrictive framework of corporations and guilds, a royal privilege gave an entrepreneur the right to circumvent local regulations. It created an exclusive right to use a new process for a given period of time; in other words, a temporary monopoly within a specified region. An exclusive privilege gave its recipient the freedom to manufacture and sell a commodity in France or abroad without encountering difficulties from competition. It was often complemented with production premiums and exemption from taxes on buildings and employees, even when the latter were migrant workers. Such privileges could also be granted to industries that had developed abroad, as was the case with the chemical production of ceruse, which is analyzed in this essay. ${ }^{2}$ In France, throughout the eighteenth century, from 1722 until the creation of French patents or brevets in 1791,

1 Jacques Isoré, "De l'existence des brevets d'invention en droit français avant 1791," Revue historique de droit français et étranger 16 (1937): 94-130, on 125; Christiane Demeulenaere-Douyère and David J. Sturdy, eds., L'enquête du Régent 1716-1718: Sciences, techniques et politique dans la France pré-industrielle (Turnhout: Brepols, 2008); David J. Sturdy, "L'Académie royale des sciences et l'enquête du Régent de 1716-1718," Christiane Demeulenaere-Douyère and Eric Brian, eds., Règlements usages et science dans la France de l'absolutisme (Paris: Tec et Doc, 2002), 133-146.

2 Isoré, "De l'existence des brevets," pp. 97-104 (see note 1); Jeff Horn, "Privileged Enclaves: Opportunities in eighteenth-century France," Proceedings of the Western Society for French History 32 (2004): 29-45.

(C) CHRISTINE LEHMAN, 2018 | DOI 10.1163/9789004325562_008

This is an open access chapter distributed under the terms of the CC-BY-NC License. 
the relations between the state and industry were managed by the Bureau du commerce. ${ }^{3}$ The latter's role was to substantiate inventors' requests for privileges and financial help from the Ministers of Commerce and Foreign Affairs. These requests usually required the opinion of a scientific expert who had to rule on the novelty of the inventions, their profitability and their impact on national self-sufficiency through the raw materials used. Until 1770, the requests for an expert evaluation that were successively addressed to academician chemists Jean Hellot (1685-1766) and Pierre-Joseph Macquer (1718-84), mainly concerned dyeing, coloring materials and the associated chemicals such as vitriol and lessive. From 1770, with Macquer and later with Louis-Claude Berthollet (1748-1822), his successor at the Bureau du commerce, they increasingly concerned the emerging chemical industry. After the Revolution, this role was taken over by the Comité du commerce et de l'agriculture that was itself replaced by the Comité consultatif des arts et manufactures at the beginning of the nineteenth century.

This essay deals with the state's influence on innovation in chemistry; it will focus on the end of the eighteenth century and on a particular chemical product: ceruse and/or blanc de plomb. Focusing on ceruse is informative for two main reasons. First, while the production of ceruse during the nineteenth century has been the subject of many studies, its history in the eighteenth century has not yet been studied. ${ }^{4}$ Second, this example provides an in-depth description of how the French administration functioned when evaluating requests for industrial privileges, thereby setting the stage for a more accurate comparison with the British context, which is presented in the conclusion.

At the end of the Old Regime, ceruse production was still artisanal and had only reached the proto-industrial stage. Its chemical formula was unknown in France and its fabrication was not sophisticated; it required only very basic equipment and workers were few and unskilled. Ceruse production is thus a quite specific case that cannot be compared with the heavy chemical industry.

3 Pierre Bonnassieux, Conseil de commerce et bureau du commerce 1700-1791. Inventaire analytique des procès-verbaux (Paris: Imprimerie nationale, 1900), "Introduction," V-xxxIV; Harold T. Parker, An Administrative Bureau During The Old Regime: The Bureau of Commerce and its relations to French industry from May 1781 to November 1783 (London: Associated University Press, 1993).

4 Laurence Lestel, Anne-Cécile Lefort and André Guillerme, eds., La céruse: usages et effets $X^{e}$ $X X^{e}$ siècles (Paris: Centre d'histoire des techniques CNAM, 2003); Thomas Le Roux, "Risques et maladies du travail: Le Conseil de salubrité de Paris aux sources de l'ambiguïté hygiéniste au XIX ${ }^{\mathrm{e}}$ siècle," A.S. Bruno, E. Geerkens, N. Hatzfeld, C. Omnès, eds., La santé au travail, entre savoirs et pouvoirs (XIX ${ }^{e}-X X^{e}$ siècles) (Paris: Presses universitaires de Rennes, 2011), 45-63, on $58-61$. 
Indeed glassmaking, porcelain manufacture, the steelmaking industries or sulfuric acid and soda production used powerful furnaces and were organized in separate workshops dealing with the successive operations. ${ }^{5}$ On the other hand, relations between the state, that is to say the royal administration of commerce, and entrepreneurs were quite similar to the case studied in this essay. ${ }^{6} \mathrm{~A}$ remarkable characteristic is that the examination of requests from both industrialists and craftsmen were treated by the same persons and the same structure with the same care. Based mainly on an analysis of the files of the Bureau du commerce, this essay presents Macquer's and Berthollet's evaluations of the processes for producing ceruse, the necessary conditions for obtaining privileges and the state's involvement in its production, which required importing lead, the customs duties of which increased the production cost. $^{7}$

Ceruse has been known since antiquity and was used as a cosmetic until the mid-eighteenth century when, due to its recognized toxicity, it was banned by medical doctors and abandoned by coquettes. ${ }^{8}$ Ceruse, or lead calx, was white lead. It had also become an important pigment used both in the East and the West over the course of centuries. ${ }^{9}$ In 1742 , the Dictionnaire universel de commerce described two methods of fabrication and defined it as "lead dissolved by vinegar." The first involved chopping lead into strips, which were soaked in vinegar, removed and scraped every ten days in order to collect a kind of crust, namely white lead, formed on the strips and do this again until lead has totally disappeared. The second, which we will call the "Dutch method," was predominant in the Netherlands during the eighteenth century. It involved hanging thinly beaten and rolled sheets of lead "in a pot, at the bottom of which is excellent vinegar, which is buried in dung; after thirty days the operation is over." 10

Charles Coulston Gillipsie, Science and Polity in France: The end of the old regime (Princeton, NJ: Princeton University Press, 1980); John Graham Smith, The Origins and Early Development of the Heavy Chemical Industry in France (Oxford: Clarendon Press, 1979).

6 Gillipsie, Science and Polity, pp. 463-78 (see note 5).

7 Liliane Hilaire-Pérez, "Invention and the State in Eighteenth-Century France," Technology and Culture 32 (1991): 911-31, on 913-19.

8 Catherine Lanoë, "Céruse et cosmétique sous l'ancien régime, $\mathrm{XVI}^{\mathrm{e}}$-XVIII ${ }^{\mathrm{e}}$ siècles," Lestel, Lefort and Guillerme, La céruse, pp. 25-37 (see note 4).

9 Philiberto Vernatti, "A Relation of the Making of Ceruse," Philosophical Transactions 12 (1677-1678): 935-36; C.M. Wai and K.T Liu, "The Origin of White Lead - From the East or the West," Journal of Chemical Education 68 (1991): 25-27. 
In spite of its harmfulness, ceruse became indispensable to painters because it yielded an irreplaceable washable and bright white paint when mixed with oil. ${ }^{11}$ In contrast with other countries, such as Spain where lime wash was used, or the Netherlands and England where this paint was only applied to wainscoting, doors and window frames, in France ceruse was very fashionable and was used to cover both the internal and external walls of buildings. Even Toulouse, "the pink city" built in brick, complied with this fashion by the end of the eighteenth century. ${ }^{12}$ A sign of embellishment and sanitation, ceruse paint beautified French cities. In 1787, the city of Paris alone consumed 300 tons of ceruse per year and its consumption in the rest of the kingdom amounted to about 700 tons. ${ }^{13}$

Because white lead was so expensive, the "ceruse" employed in France was actually not a pure product but an equal mixture of white lead, imported from Holland or England, with domestic chalk or white limestone. Consequently the word "ceruse" was misused by French painters and manufacturers during the second half of the eighteenth century. Indeed Berthollet clearly distinguished ceruse from white lead: "Ceruse always contains ground chalk with which white lead has been precisely mixed." ${ }^{14}$ This distinction tended to disappear in the nineteenth century when white lead manufacturing became common and its cost decreased. Its availability in France meant that French painters then returned to the original meaning of "ceruse."

\section{Ceruse Manufactures under the Old Regime}

France had too few white lead manufacturing plants to meet growing domestic demand. The few attempts to import ceruse as early as in 1708 or to manufac-

manure and beer vinegar. At the end of the century, the thirty-five Dutch plants produced 4,000 tons per year of white lead, of which approximatively 1,00o tons were exported to France. Ernst Homburg and Johan H. de Vlieger, "A Victory of Practice over Science: Failed innovations in the white lead industry (1780-1850)," Archives internationales d'histoire des sciences 46 (1996): 95-112, on 97-102. It caused the cruel colic of Poitou or painter's colic; François de Paule Combalusier, Observations et réflexions sur la colique de Poitou ou des peintres, Part I (Paris: de Bure, 1761). Valérie Nègre, "La peinture à la céruse et l'embellissement des villes du Midi, aux XVIII ${ }^{\mathrm{e}}$ et XIX ${ }^{\mathrm{e}}$ siècles," La céruse, pp. 39-46 (see note 4).

13 Mémoire pour le Sieur Antoine Baille, Archives Nationales (AN) $\mathrm{F}^{12} 2424$.

14 Berthollet, Rapport sur un mémoire de $M^{r}$ Valentino dans lequel il propose un nouveau procédé pour fabriquer le blanc de plomb et de céruse, 2 February 1787, AN F ${ }^{12} 1507$. 
ture it in 1736 were strictly regulated by the Conseil or Bureau du commerce. ${ }^{15}$ In the mid-eighteenth century royal decrees or lettres patentes for setting up ceruse fabrication plants could be obtained easily. For example in 1764, following a simple request, the Baron Idlinger d'Espüller and his partner the Comte de Varoc obtained permission to manufacture and sell blanc de céruse, minium, cinnabar, crystallized verdigris and oil of vitriol for ten years, "forbidding grocers and others from disturbing or troubling them" at a location specified by the lieutenant général de police. ${ }^{16}$ Before registering d'Espüller's lettres patentes, however, the Parlement of Paris requested an investigation by the Académie des sciences. ${ }^{17}$ Macquer and the physician and chemist Hyacinthe-Théodore Baron were appointed as commissioners. However, Macquer's favorable opinion, based solely on the need to replace foreign imports, was not shared by the Académie which requested that the inventors communicate their processes. The latter categorically refused because "these were the secrets on which the security and the success of their enterprise depended" and they never set up the factory. ${ }^{18}$ Until the patent law of 1791 , addressed below, commissioners generally encountered resistance when they attempted to obtain the secrets of inventions. It should also be noted that such a request for an evaluation by the Académie was quite exceptional for this type of chemical industry, as, with the exception of its interest in dyeing and at the end of the century in the fabrication of soda and saltpeter, the Académie did not show much interest in other chemical industries. ${ }^{19}$ Thus, at the end of the old regime, developing ceruse production was based on individual initiative. This development was done

15 Bonnassieux, Conseil de commerce, pp. 37(b), 39(a) and 249(b) (see note 3).

16 Holker to Trudaine de Montigny, 25 October 1764, AN F²2424; Decree of the royal council, 15 January 1765; Pierre-Joseph Macquer, "Rapport sur les demandes des Srs Idlinger baron d'Espuler et du comte de Varoc," 26 May 1766, AN F ${ }^{12} 2424$; On the location of risky factories see Thomas Le Roux, Le laboratoire des pollutions industrielles, Paris (1770-1830) (Paris: Albin Michel, 2011), 25-68.

Archives of the Académie des sciences, Plumitif and Procès-verbal of 27 November 1765, fol. $386 \mathrm{v}$.

18 Macquer, "Rapport sur les demandes des Srs Idlinger," (see note 16).

19 Ernest Maindron, Les fondations de prix à l'Académie des sciences. Les lauréats de l'Académie (1714-1880), (Paris: Gauthier-Villars, 1881); Christine Lehman, "Lart de la teinture à l'Académie royale des sciences au XVIII ${ }^{\mathrm{e}}$ siècle," Methodos 12 (2012), <http://metho dos.revues.org/2874>; Between 1776 and 1782 the Société libre d'émulation also encouraged inventors, but attention to chemistry remained limited to dyeing and distillation vessels, AN T16o ${ }^{16-22}$; AN T ${ }^{*} 160^{4-6}$; Liliane Hilaire-Pérez, L'invention technique au siècle des Lumières (Paris: Albin Michel, 2000), 209-20. 
by little-known artisanal entrepreneurs who are difficult to identify as their names generally appear only in administrative correspondence.

Requests for privileges were usually submitted to the Bureau du commerce through the Intendants, powerful royal officials who had wide-ranging responsibilities for each of the généralites into which France was divided. As discussed below, the circulation of memoirs, reports, notes, evaluations and correspondence reflects not only the pyramidal and hierarchical structure of the Bureau du commerce but also the interactions between the various actors. ${ }^{20}$ It should be noted that Macquer's mission at the Bureau du commerce, where he had been appointed commissioner in 1766, was very different from the function he performed at the Académie. It was a permanent appointment to which the title of academician was attached, but in this instance he was commissioned by the state and, like Berthollet later, he was accountable to the state - namely to the Contrôleur général - for his evaluations.

Before the Revolution, France imported between three and a half and four thousand tons of ceruse per year, mainly from the Netherlands. ${ }^{21}$ Consequently all the applicants stressed the usefulness of their invention and the economic interest of the nation. This is why Jean-Guillaume Laliaud asked the Bureau du commerce in 1779 for the right to set up a plant at Rennes, close to the lead mines of the region, which he argued would increase local employment of unskilled manpower and the region's dynamism. ${ }^{22}$

His request was examined by Macquer who had to evaluate the quality of ceruse samples sent by the Intendant of commerce Jean-François Tolozan together with those of a Dutch competitor, Guillaume-Pierre d'Espar (WillemPieter Despar). Although Bergman had shown that ceruse was composed of fixed air and litharge in 1774 his results were not yet known in France by $1779 .{ }^{23}$ Consequently Macquer followed established chemical knowledge and analytical practices and confined himself to identifying the nature of the earths that

The composition of the Bureau and its operation underwent many modifications between 1722 and the end of its activity in September 1791. See Bonnassieux, Conseil de commerce, "Introduction" (see note 3); Parker, An Administrative Bureau (see note 3). than 1,00o tons in 1779 according to Laliaud (AN $\mathrm{F}^{12} 1507$ ); 2,409 tons in 1787 according to the Journal des mines 1 (1794): 92; 3,000 tons in 1788 according to d'Espar (AN F121507); 4,000 tons in 1790 according to Migneron de Tocqueville ( $\mathrm{AN} \mathrm{F}^{12} 2424$ ); 1,200 tons average between 1787 and 1789, according to Héricart de Thury, Rapport du Conseil des travaux publics du département de la Seine sur la... céruse de Clichy... 1815. l'Hérault, C7612, fols. 352-53 ; Jean-Guillaume Laliaud, Dossier "Céruse," AN Fi21507.

See note 45 for details. 
composed the sample substances and measuring their proportions. He deemed both men's samples to be "made of half white lead and half very white marly earth (limestone and clay), rather weighty, well cleaned of sand and soft to the touch." ${ }^{24}$ The general qualities of the two samples seemed to be identical to or even higher than those from Holland. With regards to their practical use, Macquer relied on the opinion of professionals (house painters, merchants and colour makers), specifically on the renowned painter-gilder Jean-Félix Watin. ${ }^{25}$ The specimens of ceruse submitted by both applicants passed Macquer's tests: they had a good covering capacity and body. Macquer gave his favorable opinion because there were "presently no manufactures for these materials in France," demand was constantly increasing, the raw materials needed for ceruse manufacturing were available domestically and the climate was more favorable than in the Netherlands. But success also depended on fresh capital, chemical knowledge and operational know-how. Laliaud had the advantage here as he had already performed full-scale operations in a plant he had acquired at Langoyran near Bordeaux. This was not the case for d'Espar, who had to prepare white lead and ceruse in the presence of specially appointed commissioners.

Macquer's opinion convinced the government, which granted Laliaud authorisation on 15 February 1780 to establish ceruse and white lead manufactures in Normandy, Orleanais, Provence, Languedoc and Guyenne, with incentives for production in the form of tax exemptions and premiums. ${ }^{26}$ These locations had strategic importance: Orleanais and Normandy supplied Paris, Languedoc and Provence promoted trade routes to the East and Guyenne across the Atlantic. In order to balance the advantages given to Laliaud, d'Espar requested Brittany, the Ile de France, Champagne, Nivernais, Lyonnais and Dauphiné (see Fig. 6.1). ${ }^{27}$

For this purpose d'Espar founded a company with two nobles from the Nantes region, Jean-Louis d'Adhémar de Montréal and Philippe-Vincent-Roger de la Mouchetière, lieutenant-général of the Nantes Admiralty, who provided

\footnotetext{
24 Macquer, "Projets d'établissemens de manufactures de blanc de plomb et de céruse en France," 7 September 1779, AN F ${ }^{12} 1507$.

25 Jean-Félix Watin, Art du peintre doreur et vernisseur (Paris: Grangé, 1772).

26 AN Fi21506; "Réponse des Intendants de province à la lettre qui leur a été adressée le 24 janvier 1788," AN Fi21507.

27 D'Espar's memoir, AN F ${ }^{12} 2424$; Tolozan's response is in a letter of 23 December 1779, AN $\mathrm{F}^{12} 1507$.
} 


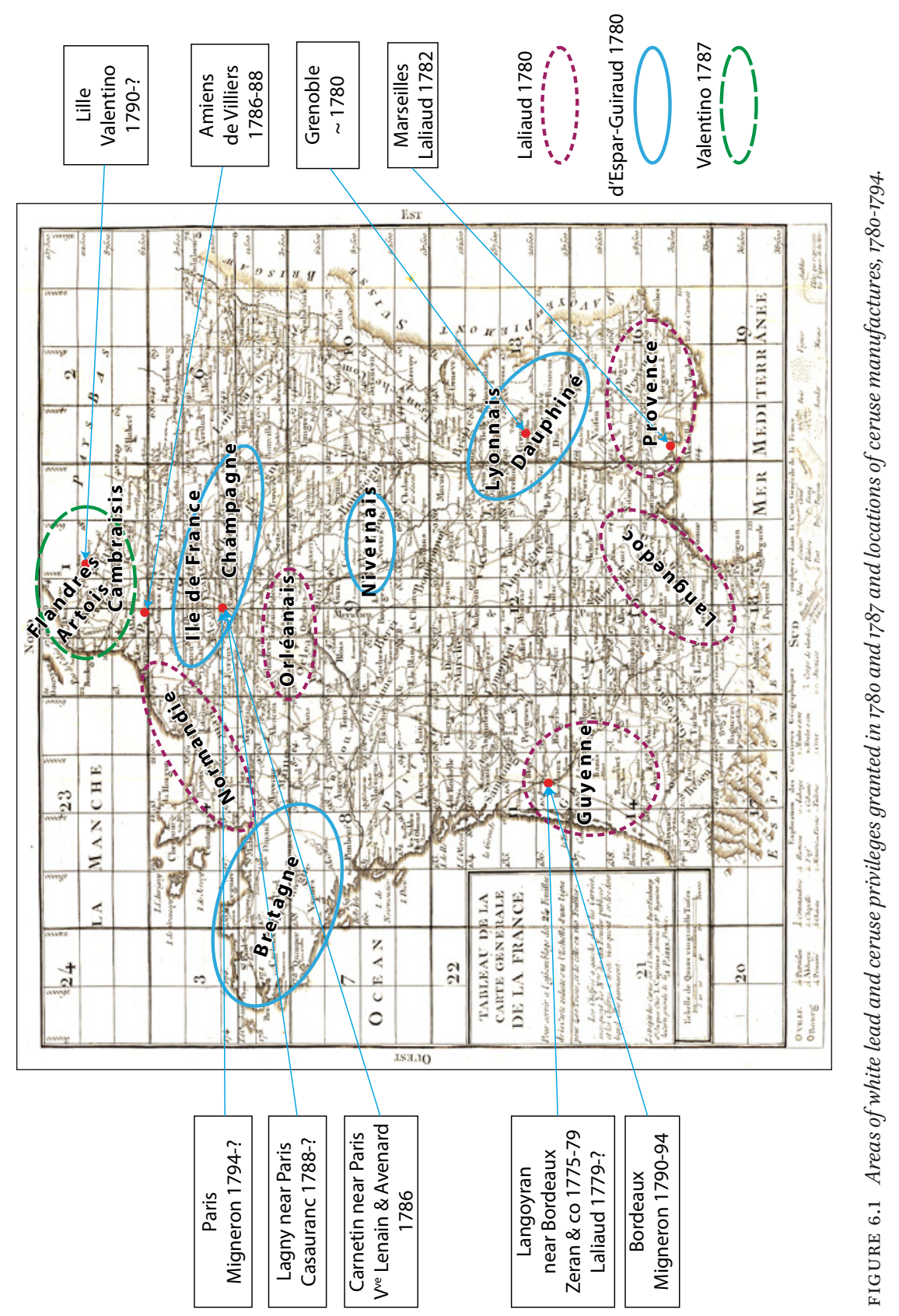


the necessary funding. ${ }^{28}$ This company was founded under the name of Guiraud et compagnie. Jean Guiraud was a bourgeois of Paris, who brought his influence and notoriety, that is to say "his guarantee and his name," to support the request for a privilege. ${ }^{29}$ On 18 July 1780 , Guiraud et compagnie obtained the privilege to "make, distribute and retail white lead and ceruse in the requested provinces" for six years and with the same financial advantages as Laliaud's.$^{30}$ With these sites distributed around the kingdom, the state intended to match the national demand for ceruse while preventing other plants from being set up. ${ }^{31}$ But both enterprises failed, first Laliaud's, which received 5,500 livres between 1781 and 1785, but produced little ceruse. The reports, issued in 1788 by the Intendants in the various provinces involved, underscored the failures: Laliaud's plant, established in Marseilles in 1782, had just changed ownership and the one in Dieppe had produced nothing yet; meanwhile d'Espar-Guiraud's manufactures had not been created. Consequently, in 1788 there was still hardly any white lead production, despite the state's will and generosity. Not only did the privileges and financial help granted to Laliaud and d'Espar and company not succeed, their exclusivity, forbidding the establishment of other plants, frustrated the industry's development.

The case of Damelon, a former cavalry officer, demonstrates this contradiction. Damelon claimed to draw his knowledge of the fabrication process from his many travels to Venice, Holland and especially Nuremberg. As Laliaud and d'Espar-Guiraud's manufactures had not been exploited after five years, on 8 august 1785 he applied to the Contrôleur général for the repeal of Laliaud's privilege and for the same financial aid. After gathering the necessary funds, he intended "to develop this essential business [...] that we can take from our jealous neighbours." ${ }^{32}$ In response to this request, the requirements of the Bureau

28 Contract dated 9 June 1780, AN, MC/ET/XLIV/545; George V. Taylor, "Types of Capitalism in Eighteenth-Century France," The English Historical Review 79 (1964): 478-97, (on 495-96).

29 Contract dated 15 February 1781, MC/ET/XLIV/549; AN, MC/ET/XLIV/545; See also the contract of 4 February 1783 between a painter, Antoine Meraud who held the secret, and a priest Jean-François Girou de Montdésir, who provided funding and took care of obtaining the privilege for establishing a white lead and ceruse plant near Paris, AN, MC/ET/ LXV/461.

30 AN, MC/ET/XLIV/545.

31 Such as the one from Desomer on 18 March 1780 , (AN Fi22424) or Dubreuil de la Gueronnière who on 18 July 1783 was refused permission to install a plant in the abbey of Cercanceaux near Nemours, AN Fi2 1507 .

Damelon to Merelliers?, 16 October 1785, AN F'12 1507. 
du commerce were still the same: give evidence of both knowledge of the process and support by funders. ${ }^{33}$

The experiments were performed before Berthollet, who had first to check whether Damelon's process was different from Laliaud's and carry out a profitability analysis. In his report, Berthollet gave a favorable opinion, although three attempts were required before getting an acceptable result from painters. On condition that Damelon improved the grinding by using new mills, Berthollet judged that the enterprise could compete with foreign competition if "prudently" managed. Damelon's process was the well-known Dutch method and therefore not original. Nonetheless Berthollet added what became a leitmotiv, that "it would be beneficial to take away this branch [of industry] from foreigners." ${ }^{34}$ After Berthollet's positive assessment, Damelon still had to provide evidence of his financial support. He responded by withdrawing his request for support, arguing that:

If it succeeds, he [Damelon] will have acted for the good of the state since he will prevent several millions per year from leaving the kingdom to purchase this substance from abroad. If it does not succeed, it will have cost the state nothing. ${ }^{35}$

Damelon relied instead on his influential protectors: Brissault de la Chapraie, who promised to secure the necessary funds; Monsieur (the King's brother), who was ready to grant a piece of land south-east of Paris, upon which to establish the manufacture; and the Comte d'Alsace, who invoked the threat of losing know-how to the benefit of England, which the French believed to be practicing freedom of trade. ${ }^{36}$ Disappointed by the previous agreements concluded with d'Espar-Guiraud and Laliaud, who had just sold his privilege, the minister waited for a better guarantee from the funders before giving Damelon a favorable answer. But by now Damelon had competitors. In 1785 Valentino, a chemist at Lille's military hospital, submitted a request for a privilege. ${ }^{37}$ The following year someone named Caille made a similar request for Paris and several other provinces and de Villers established a plant in Amiens without state

Merelliers? to Damelon, 21 January 1786, AN F12 1507 .

36 Comte d'Alsace to Tolozan, 5 August 1787, AN F² 1507.

37 Bonnassieux, Conseil de commerce, p. 449(a) (see note 3 ). 
help. ${ }^{38}$ In 1788 d'Espar sought to recover the privilege he had been granted in 1780 and to establish a new manufacture near Bordeaux. ${ }^{39}$ Due to the similarity of these applications, the Bureau du commerce decided to consider ceruse production from a more general viewpoint. In July 1788 , it carried out "a new examination of the various means of introducing and maintaining the fabrication of ceruse in France" and rejected Damelon's request. ${ }^{40}$ The commissioners realized that the profitability of ceruse fabrication was closely related to customs duties on lead. However, decreasing these duties would prejudice French mining entrepreneurs and it was decided that "lead extraction was more necessary than ceruse fabrication." Finally Damelon did not install his ceruse manufacture and withdrew his file on 2 July 1792, seven years after his initial application.

In August 1785, Liborio Philippe Valentino (1741-1803) also applied to open a ceruse manufacture. Unlike Damelon, Valentino was a chemist. ${ }^{41}$ An Italian immigrant, he had settled in Lille in 1779 where he was apothecary at the military hospital. As the director of a large-scale manufacture of oil of vitriol and aqua fortis he already possessed industrial know-how. ${ }^{42}$ In 1785 he was involved in the creation of a learned society, the Collège des Philalèthes, which grew out of the masonic lodge Les amis réunis. These ties with freemasonry and the industrial world enabled him to get financial support from three of Lille's most powerful merchants and one of the city's notables. Due to the cost of raw materials, lead and vinegar, it seemed impossible to match foreign competition. Valentino answered this challenge by proposing an innovative method for manufacturing white lead, in which vinegar was replaced with brine. Since the gas analysis of native ceruse from English mines yielded only fixed air, why not imitate nature? He therefore poured salted water onto heated lead "at a heat sufficient enough to set paper alight." After scraping the crust that formed, he exposed this lead to air for a relatively long time while drizzling it regularly with brine. The operation was repeated until all the lead was consumed. ${ }^{43}$ (See Fig. 6.2.) Interestingly, a similar process was patented in Great Britain a few years later in 1797 by the Scottish chemist Archibald Cochrane, Earl of

38 Note of 9 August 1786, AN F ${ }^{12}$ 1507; Bonnassieux, Conseil de commerce, p. 455(b) (see note 3).

39 Ibid., pp. 453, 454(a) and 455(b).

$40 \quad$ Ibid., pp. 459(b), 46o(a).

41 "Chimiste pensionné du Roy at the Lille military hospital," AN Fi2 1507, dossier Valentino.

42 Valentino to the Ministre d'état, 1788, AN F ${ }^{12} 1507$.

43 Nouveau procédé pour fabriquer le blanc de plomb et la céruse sans faire usage du vinaigre, par Valentino chimiste penssionné du roy à la suite de l'hôpital militaire de Lille en Flandres, AN $\mathrm{F}^{12} 1507$. 


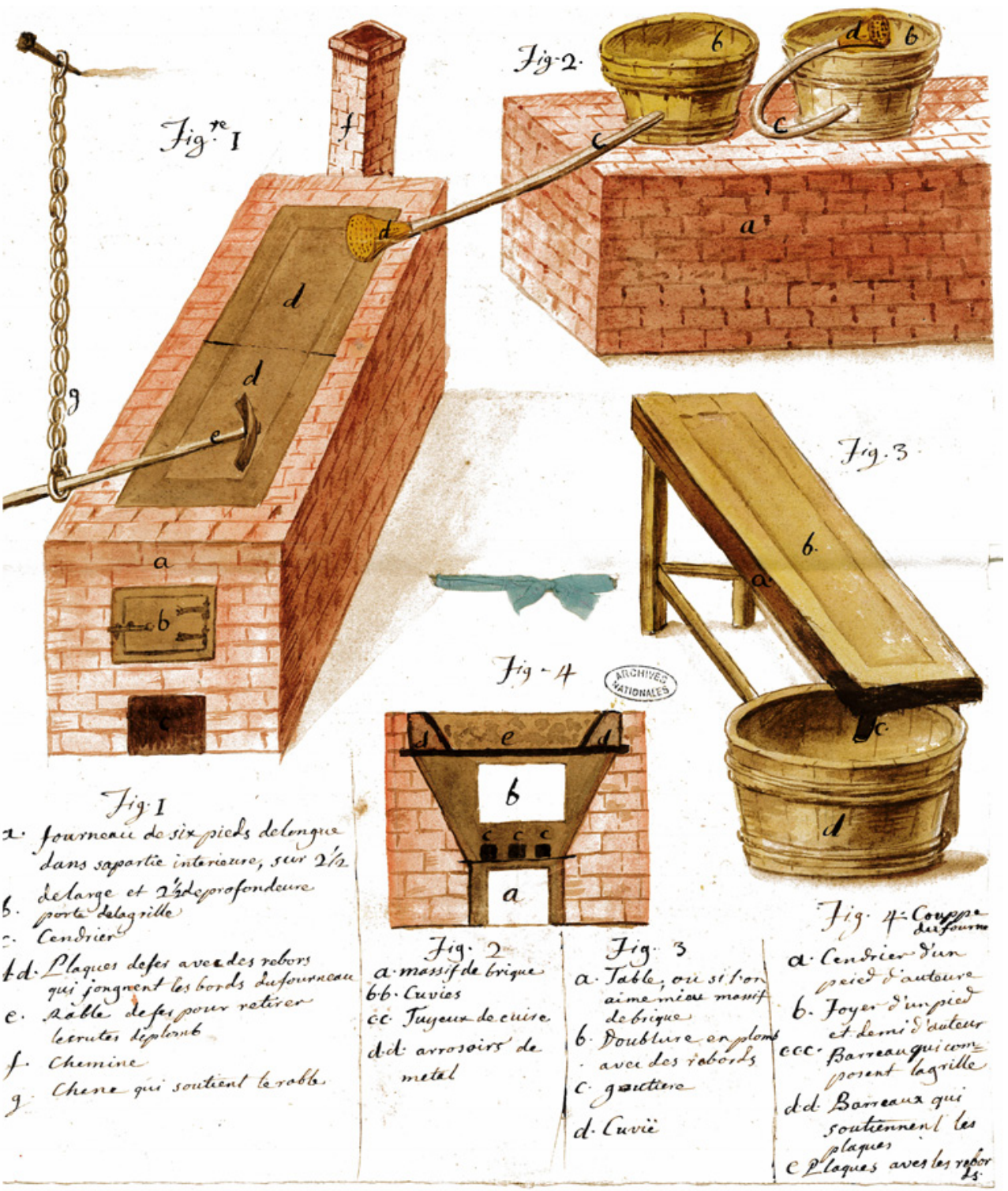

FIGURE 6.2 Valentino, New process for manufacturing white lead and ceruse without using vinegar (AN $\left.F^{2} 1507\right)$. COURTESY OF ARCHIVES NATIONALES, PIERREFITTE-SURSEINE. 
Dundonald, by reacting muriate of potash (another chloride) instead of brine with lead calx before exposing it to a flow of carbonic acid gas or atmospheric air. ${ }^{44}$ It was only after Torbern Bergman's analysis of white lead in 1774, which showed that it was a compound of fixed air and litharge, that these empirical methods of manufacture became understandable. ${ }^{45}$ However this research seems to have been unknown in France, noted neither by Macquer nor Berthollet.

With the support of Charles-François-Hyacinthe d'Esmangart, Intendant des Flandres et d'Artois, Valentino applied for a ten year exclusive privilege and 10,00o livres to cover his research costs. ${ }^{46}$ The answer was not long in coming: Valentino was required to have his process checked and "in the event that his process is recognized as new and useful by gens de l'art as well as by the council $S^{r}$ Valentino will be treated favourably."47

Berthollet provided a qualified opinion, criticizing Valentino's lack of precision and adding that his experiments "did not announce a chemist enlightened by an exact theory." 48 He nonetheless advised having examinations carried out by reliable persons, and Valentino complied with this new requirement. After building a new furnace in April 1787, he again performed his process before two experts commissioned by the Intendant of Lille. The verification took place almost every day from $7 \mathrm{am}$ to $8 \mathrm{pm}$. Seals were applied and everything was weighed and measured: the number of brushwood stacks used for fire and the quantities of heated lead, coal and marine salt. The dephlogisticated lead (the name often given to white lead) that was extracted during the course of operations was thrown into a barrel filled with water. On the following day the solid parts were washed, weighed and packed. The ceruse prepared by mixture with various proportions of Champagne chalk was also placed in sealed boxes to be sent to the Bureau du commerce. Valentino's process was deemed much more economical than the Dutch one: marine salt was less expensive than vinegar; the charcoal used in the furnace in order to melt the lead and perform the

44 Archibald Earl of Dundonald, "Methods of Making Ceruse or White-lead," 18 August 1797, The Repertory of Arts and Manufactures 8 (1798): 377-81.

Klaproth replicated this analysis and found $84 \%$ litharge (lead oxide) and $16 \%$ carbonic acid. White lead was therefore lead carbonate. Homburg and Vlieger, "A Victory of Practice," p. 103 (see note 10); Gérard Emptoz, "Un procédé de fabrication de la céruse issu de la 'chimie moderne' au début du XIX ${ }^{\mathrm{e}}$ siècle," Lestel, Lefort and Guillerme, La céruse, pp. 49-6o (see note 4).

46 The Intendant of Lille even proposed contributing half the financial support, d'Esmangart to Blondel on 27 December 1785 , AN F ${ }^{12} 1507$.

47 Note by Cotte dated 22 March 1786, AN F 1507.

48 Berthollet, Rapport sur un mémoire de $M^{r}$ Valentino (see note 14). 
necessary operations was less expensive than dung; lead was used in ingots as extracted from mines and did not need to be cast into thin blades and wound into spirals. It was also less time-consuming, taking twenty-four hours with a well-designed workshop versus eight to ten months for the Dutch process. Apart from the advice to operate the furnace continuously, the verdict totally favored Valentino. ${ }^{49}$

After complying with the orders of the government, Valentino submitted his requests to the Bureau du commerce. In addition to financial assistance of 20,00o livres that would enable him to meet his expenses, pay back his creditors and borrow again, he applied for the exclusive privilege to manufacture and sell his ceruse in the provinces of Flanders, Hainault and Cambraisis, tax exemption on drink and living costs for the workmen and especially exemption from customs duties on lead and other raw materials that would help him to compete with British ceruse. Indeed, in addition to readily available lead mines, the latter was also benefiting unfairly from premiums granted by the British government: "from five to ten per cent for some articles of all goods exported to foreign countries." 50 Moreover, as he had revealed his secret to experts who had not been sworn in, he feared being dispossessed of the secret, should it to be disclosed. Valentino therefore considered it impossible to start his enterprise without the state's help. As with Damelon, the threat of his secret being leaked to foreign countries was repeatedly invoked by d'Esmangart to pressure the government into granting the requested help.

I know that foreign traders informed by this chemist's discovery and the advantages of his process for fabricating white lead and ceruse have made him considerable and advantageous offers in order to incite him to cross to their side and create his establish there. ${ }^{51}$

When the government compels the inventor of a profitable discovery to disclose the process, it seems to tacitly commit itself to granting him compensation in proportion to the sacrifice of a secret which is his own property. $^{52}$

49 Report by Merlin physician at the Lille military hospital and Boudin chemist apothecary at Lille, Procès-verbal ordonné par Mons ${ }^{r}$ Esmangart, Intendant des Flandres et d'Artois, et exécuté par le Sieur Valentino chymiste attaché à l'hopital militaire de Lille pour la fabrication de la céruse, 25 mai 1787 (copy dated 26 September 1788), AN F'12 1507.

$5^{0} \quad$ Valentino to d'Esmangart, 25 May 1787 , AN F ${ }^{12} 1507$.

$5^{1} \quad$ D'Esmangart to Tolozan, 25 February 1788. See also d'Esmangart to Blondel, 27 December 1785 and to Tolozan, 27 October 1787 , AN F ${ }^{12} 1507$.

$5^{2}$ D'Esmangart to Tolozan 7 December 1787 . Valentino was strongly supported by d'Esmangart who was acting for the development of his province and intervened with the Bureau 
On 31 October 1787 , the government finally responded by granting Valentino the exclusive privilege of manufacturing, selling and distributing in Flanders, Artois, Hainault and Cambraisis for five years only, while "forbidding disturbance of the owner in the operation of his manufacture." (See Fig. 6.1.) This exclusive privilege was all the more easily granted since this region did not overlap with those of Laliaud and d'Espar-Guiraud, which was not the case for Damelon. Paradoxically, Valentino refused the privilege saying that its duration was too short and would prevent him from making the installation profitable. Moreover, his request evolved over time. In 1788 , he mentioned the purchase of a large piece of land on which he built his manufacture, claimed the title of Royal Manufacture and maintained his requests for the exemption of excise duty on his consumption and his workers' as well as exemption from customs duty on lead and other raw materials. It was this stubborn request for getting both the commercial privilege and the tax exemption on lead that created tension between Valentino and the government.

Let us look first at the exclusive privilege. In order to ensure equity as well as a harmonious and balanced distribution of plants of this type throughout the kingdom, the Bureau du commerce inquired about the presence of other ceruse plants in the north of France and the possible privileges granted to them. It was in this context that the Intendant of Amiens reported that a ceruse plant using the Dutch process had been established there by de Villers in 1786. Apart from the fact that Valentino's request seemed excessive with respect to de Villers', the deputies of the Bureau du commerce agreed on the position that distributing premiums should only be done in extreme situations, which was not the case for ceruse because "the art of making ceruse is not a secret, all chemists know it." ${ }^{\prime 3}$ Although they did not jeopardise the exclusive privilege in the provinces already granted to Valentino, they declared that "in the future these kinds of favours would have no other results than holding industry back and preventing other establishments that we would like to see increase in number." 54 This shows that the commissioners had come to consider the attribution of exclusive privileges as potentially harmful to the country's industrial development. In the end, in spite of his stubbornness and supporters, four members of the Bureau du commerce, the Intendant of Flandres and the administrators of the department du Nord, Valentino obtained no other

du commerce on several occasions, 24 September $1788, \mathrm{AN} \mathrm{F}^{12} 1507$.

53 Draft note on a letter of 15 March 1788 and Deliberation of the députés du commerce, 3 June 1788 , AN F ${ }^{12} 1507$.

54 Avis des députés du commerce sur la demande de deux fabriquants de céruse [Villers et Valentino], 9 May 1788, AN F'12 1507. 
encouragement. Indeed, from 1790, the financial situation of the central government was no longer favorable and it now became the responsibility of local administrations to support their manufactures. ${ }^{55}$

Furthermore the request for exemption from customs duties on foreign lead reflects a real difficulty. Valentino claimed that the problem of ceruse manufacturing came from the fact that only a part of the lead used could come from French mines, "which made lead very expensive for those who would attempt such an undertaking in France." Indeed there was an imbalance between the customs duties on lead imported from England, 4 livres 10 sols per quintal, and the much lower ones paid by Dutch manufacturers. This was not balanced by customs duties on foreign ceruse, 1 livre 2 sols 6 deniers per quintal. ${ }^{56}$ Thus France could not match countries that had lead mines and granted premiums on the ceruse that they exported. During their deliberation of 3 June 1788 , the commissioners recognized this difficulty. They acknowledged that the failures of ceruse plants came from the excessively high customs duties on lead and the overly low ones on ceruse, which penalized national ceruse production, and they confessed to having forgotten a basic principle of trade administration:

This principle is that one must propose a much higher import duty on the fabricated product than on the raw material it is made from. We have lost sight of this principle when taxing lead at a rate three times higher than the one applied to ceruse \& this oversight has caused all the enterprises we have established to fail..$^{57}$

The deputies then proposed to reduce the customs duties on foreign lead and to increase the duties on ceruse. The advice of the Bureau du commerce reflects the commissioners' hesitations. Some of them were in favor of premiums granted to ceruse manufacturers such as exempting them from lead duties; others thought that it would probably be more advantageous to develop lead extraction in France by creating new mines in order to meet national demand. .5 The enquiry carried out by the Inspecteurs généraux des manufactures showed that 80,000 quintaux of lead and 24,00o quintaux of ceruse were imported in $1784 .{ }^{59}$ One of the Inspecteurs des mines, Jean-Pierre-François Guillot Duhamel,

55 Tolozan to Valentino, 9 juillet 1790, AN F $\mathrm{F}^{12} 65^{2}$.

$5^{6} \quad$ Avis des députés du commerce, 9 May 1788 (see note 54); See the case of de Villers' establishment, draft letter by the Bureau du commerce, AN F ${ }^{12} 1507$.

57 Avis des députés du commerce, 9 May 1788 (see note 54).

$5^{8}$ Deliberation of 22 October 1788 , AN Fi2 1507.

59 Antoine-Marie Héron de Villefosse, De la richesse minérale (Paris: Levrault, 1810), 397. 
evaluated the production of national mines to be just one fourth of national consumption. ${ }^{60}$

Although customs duties on lead were decreased to 3 livres and those of ceruse increased to 3 livres 10 Sols per quintal on 1 June 1789 , Valentino maintained his demand of a total exemption from customs duties on lead. ${ }^{61}$ His stand was supported by all ten administrators of the département du Nord. ${ }^{62}$ However, the decision of the deputies of the Bureau du commerce on 13 May 1791 remained the same: there was no reason to favor Valentino over other manufacturers. Indeed:

This type of fabrication is not profitable enough to push the Treasury to make the financial sacrifice it would demand. Besides, a more important consideration would further militate against the requested exemption, that is the interest of the national mines which could no longer be operated if foreign lead, whatever its final destination, entered France without paying duties. ${ }^{63}$

The Minister also advised Valentino to turn to the Comité d'agriculture et du commerce. ${ }^{64}$ Thus Valentino's factory, in operation from the beginning of 1790, seems to have received no help from the state. It is not known how long it remained in operation.

The increase of customs duties on ceruse imports remained a reason for refusing all new privileges for ceruse or white lead manufacture. This is why, in 1790, Migneron de Brocqueville was dismissed when he applied for an exemption from internal taxes and export duties and for a premium on the ceruse produced in his Bordeaux factory with a "Dutch céruzier."65 Yet this ceruse had been favorably evaluated by the academicians of Bordeaux. It was very white and friable and its analysis showed that it was "a true lead calx, with no

60 "Avis des Inspecteurs généraux du commerce sur les demandes des S ${ }^{\text {rs }}$ Valentino, de la ville de Lille; et du Sr Villers, de la ville d'Amiens," 10 July 1788, AN F ${ }^{12}$ 1507; At the end-of the eighteenth century, France produced 2,00o tons per year of raw lead, while Great Britain extracted 10,000 tons. Lynn Willies, "Derbyshire Lead Mining in the Eighteenth and Nineteenth Centuries," Mining History 14 (1999): 31-33.

61 Arrêt du Conseil d'état du Roi du 23 avril 1789 (Paris: Imprimerie royale, 1789).

62 Administrateurs du directoire du département du Nord to Tolozan, 1 February 1791, AN F² 1507 .

63 Avis des députés du commerce, 13 May $1791, \mathrm{AN} \mathrm{F}^{12} 1507$.

64 Mémoire soumis à l'Assemblée nationale par le Sr Valentino, 27 June 1790; Valentino to the deputies of the Comité d'agriculture et du commerce, 26 July 1790, AN F ${ }^{12} 652$.

65 Necker's answer to the letter sent by Migneron on 6 March 1790, AN, F ${ }^{12} 2424$. 
addition of marly earth or other material, so that it could be easily reduced to lead." 66 One can see that, as early as 1790, what was called ceruse had started to become pure white lead again. In deference to the Intendant of Bordeaux who had sent the samples, Migneron's ceruse was evaluated by Berthollet but this was a mere formal exercise since the privilege had been refused from the beginning. Thus Berthollet only judged the external qualities of this ceruse that in his opinion did not look enough like the Dutch product, once again revealing the force of painters' habits. Dutch ceruse had become the standard, which created an additional handicap for all attempts at producing it nationally. In any event, the lack of competitiveness of French ceruse was irreducible. As Berthollet noted, France could not stand up to foreign competition due to "economic combinations and the modest profits accepted in several Dutch establishments," echoing Migneron's criticism, according to which increasing the customs duties on ceruse "did not balance the low cost of manpower in Holland in comparison to its high cost in France."67

\section{The Revolutionary Period}

From the beginning of the new Republic the problem of the supply of ceruse became crucial as France was at war with both England and the Netherlands from 1793. Paradoxically, the same Migneron who had suffered a categorical refusal by the Bureau du commerce now got support from the state and, instead of a financial grant, received material help to install a new factory in Paris. For example he was given 200 quintaux of lead thanks to the support of the Comité d'agriculture et du commerce and the National Convention. His process was derived from the Dutch method, but instead of earthen pots he used "lead boxes, the construction of which and their arrangement in dung were specific to him," which required a large quantity of lead. The implementation of the process was placed under the oversight of two chemists, Bertrand Pelletier and Nicolas Leblanc. ${ }^{68}$ The country was at war and he was only granted the lead after the Commission des armes et poudres agreed. ${ }^{69}$ Favors did not stop there. The Comité des finances assigned him a house belonging to the state, which he rented from 10 nivôse an III (30 December 1794) and in which he set up his establishment. The Commission du commerce supplied him wood, coal,

66 Report dated 7 February 1790, AN, F' 2424.

67 Berthollet's report, 6 April 1790, AN, $\mathrm{F}^{12} 2424$.

$68 \quad \mathrm{AN}, \mathrm{F}^{12} 2424$ and $\mathrm{AF} / \mathrm{II} / 11$.

69 Thury, Rapport du Conseil des travaux publics, "États de l'importation du plomb" (see note 21 ). 
candles, oil and products of basic necessity. Finally, the Committee of Public Safety allowed him to use marble from former tomb covers in order to make the millstones for grinding the calcined lead while protecting his workers' health. ${ }^{70}$ Thus under the auspices of the newly founded Republic, from the end of July 1794 to the end of February 1795, Migneron successfully installed a ceruse factory in Paris, which would have been practically impossible at the end of the Old Regime, given the price of lead and the absence of aid from the state.

Another entrepreneur, Simon-Léon de Casauranc de Saint Paul, was less lucky although he had been running a ceruse manufacture since 1788 at Lagny near Paris and had applied for a patent in $1792 .{ }^{71}$ The specificity of his process was sieving limestone and washing it with water from the fountain in Lagny market before mixing it with ready-made white lead, which the patent application claimed deserved the title of perfectionneur (improver). His request for increasing the customs duties on ceruse was rejected by the Comitédu commerce that wanted to ensure competition with foreign ceruse in order to maintain the quality of French ceruse. As regards his request for used lead, he was directed to the war ministry. ${ }^{72}$ Since the lead needed for manufacturing white lead was requisitioned, its supply was left to the goodwill of the Commission des armes et poudres. During the revolutionary period the creation of ceruse plants was limited by a restricted supply of lead and, even with a patent like Casauranc's, getting help from the state was difficult for an entrepreneur.

The system of privileges granted by the King following the examination of a request by the Bureau du commerce was entirely recast in 1791 and the two laws of 7 January and 25 May reduced the power of the crown and gave increased protection to the inventor. The law of 7 January dealt with the patente dinventeur and established the property rights of the inventor in his invention while that of 25 May stated that "national patents called brevets dinvention would be delivered by the King on a simple request and without prior examination. ${ }^{73}$ The protection of the secret of the invention during a period of five, ten or fifteen years was a significant step forward if recalling d'Espüller's refusal to disclose his processes to Macquer in 1765 and Valentino's long hesitations, but it had to be described by a specification of the process.

$70 \quad$ AN, F ${ }^{17}$ 1037; "Nouvelles manières de préparer le Blanc de plomb ou Ceruse," Annales des Arts et manufactures 1 (1800): 48-63, 55-58.

$71 \quad$ Brevet d'invention de cinq années pour la fabrication du blanc de céruse façon de Hollande au $S^{r}$ Casaurans perfectionneur, 19 January 1792: $\mathrm{n}^{\circ} 1 \mathrm{BA1942.}$

72 Casauranc to the representatives of the Comité du commerce, 19 pluviôse an III (7 February 1795), AN F $\mathrm{F}^{12} 2424$.

73 On the change brought by the laws of 1791, see Isoré, "De l'existence des brevets," pp. 97-104 (see note 1). 
In the middle of the eighteenth century, disclosing one's secret implied a risk, as during the full scale tests required for industrial implementation the inventor was not protected against possible indiscretions by workers. Moreover the granting of a royal privilege was more stringent as it required not only novelty but also examination by an expert (Macquer or, later, Berthollet) in order to evaluate its commercial profitability in view of a possible industrial implementation and, lastly, the obligation to build and operate the plants that were approved, as we have seen in the cases of Laliaud and of the association Guiraud and company founded by d'Espar. Beneficiaries of privileges also had to prove the robustness of their enterprise and of their funders. In return, the state was generous and proposed real financial support for development and production. However, after the laws of 1791, while inventors remained the owners of their secrets, they were still compelled to find private funds to found their enterprise, as the state granted no financial aid to the applicants. On the contrary, the latter had to pay a tax of 300 livres for a patent of five years, 800 livres for ten years or 1,500 livres for fifteen years. ${ }^{74}$ Furthermore patents did not require strict novelty as an importer of a foreign process had the same rights as an inventor. ${ }^{75}$ Indeed, when looking at the patents dealing with white lead and ceruse fabrication filed between 1791 and 1820, it appears that they were not always exploited and often borrowed from abroad. ${ }^{76}$

\section{Conclusion}

Although the ceruse industry was only emerging, the study of this particular chemical industry in the last decades of the eighteenth century reveals the conditions for obtaining a royal privilege. Without technical know-how or financial support and with no influential connections, it was difficult to get a privilege. The extensive file devoted to Valentino's case, held in the Archives Nationales, contains more than one hundred documents, which provide insights into the functioning of the Bureau du commerce and its evolution during the pre-revolutionary period until its disbanding in 1791. It can be represented in a simplified way by the following diagram. (See Graph 6.1).

74 Valérie Marchal, "Brevets, marques, dessins et modèles. Évolution des protections industrielles au XIX ${ }^{e}$ siècle en France," Documents pour l'histoire des techniques (2009): 106-16, on 111 .

75 Isoré, “De l'existence des brevets," p. 103 (see note 1).

76 Institut national de la propriété industrielle [INPI], base de données des brevets français du $19^{\mathrm{e}}$ siècle, <http://bases-brevetsige.inpi.fr/> (accessed 31 March 2016). 


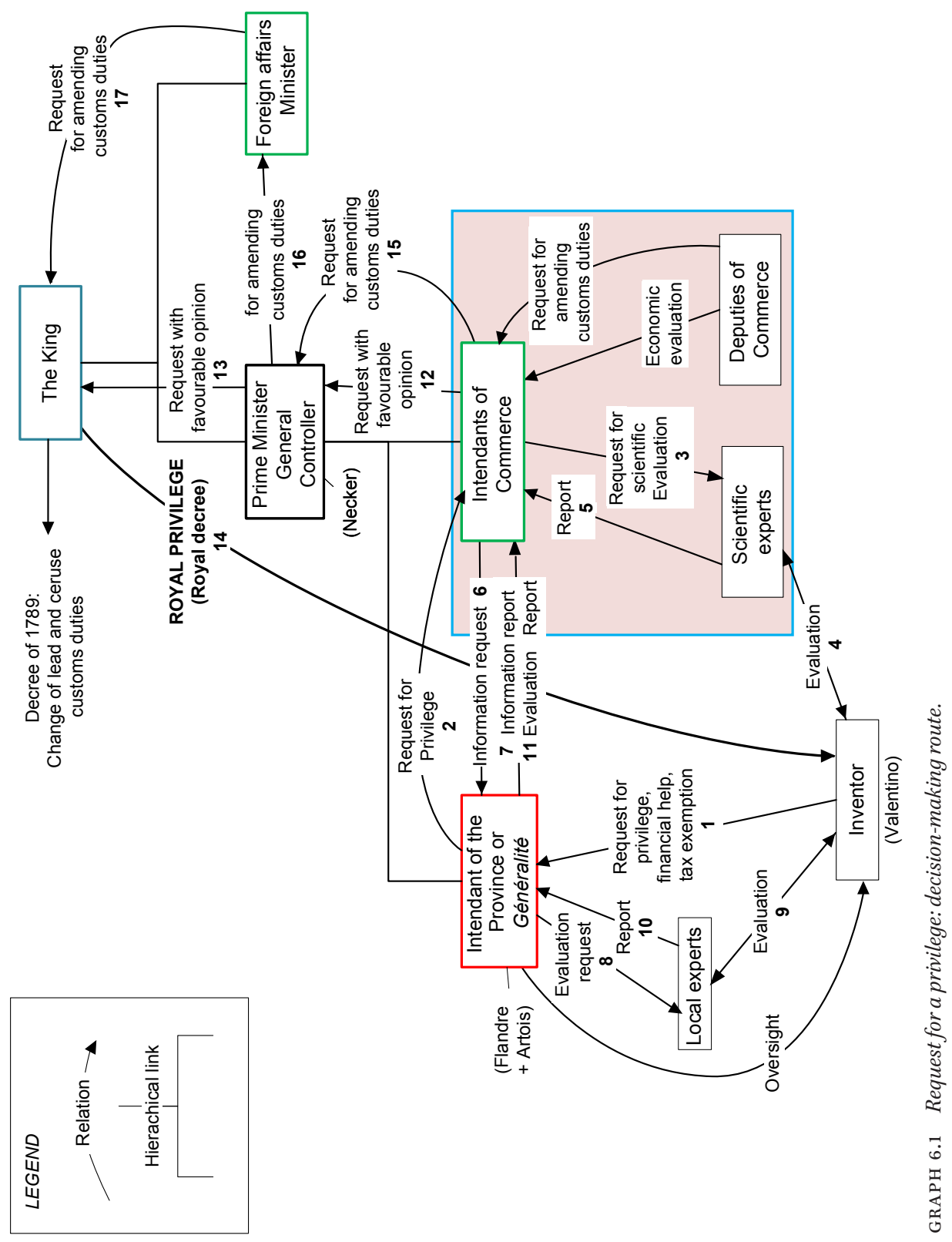


This diagram shows that the Intendant in the province was only an intermediary and that the members of the Bureau du commerce, as well as the Contrôleur general, had an advisory role only. The final decision was exclusively in the king's hands and the privilege was granted by a royal decree. However the diagram also shows a real freedom in the multiple exchanges between the applicant, a private individual, such as a chemist-apothecary at a hospital in Lille, the Intendant of the city, the intendants and commissioners of commerce and the minister. This enlightened organisation contrasts with the usual image of the absolutist state. One can also note the fairness, the seriousness of the answers and the patience of the Bureau du commerce, which took pains to rule three times on Valentino's requests. ${ }^{77}$ The six-year duration of Valentino's case also shows the evolving position of the government and the difficulty of reconciling the need for free trade of lead with the national income generated by the mines of the kingdom. On one hand, the applicant owned his secret and could threaten to exploit it abroad. On the other hand, the state had the power to grant the privilege and the financial aid associated with it, but it had to cope with the complexities of international trade, protective tariffs and competition between various production sectors such as lead mines and ceruse manufactures.

The exchanges that preceded granting a privilege as a compensation for a service performed by the inventor for the well-being of the nation, argue against the current idea of a French absolutist state as opposed to the British system, which was deemed to be liberal due to the fact that it was based on individual right ${ }^{78}$. It should be noted that eighteenth-century Britain was still not free from monopolies, the damaging effects of which were highlighted by Adam Smith. ${ }^{79}$ Before being superseded by the 1791 patent laws, French royal privileges were very different from the monopolies to which Smith referred and should rather be compared with Britain's patent system in spite of their differences. Both were granted by the king and created a temporary monopoly. Both needed a full description of the invention but, in contrast with British patents, which required no preliminary examination, the novelty and usefulness of French inventions had to be established by means of scientific

77 On 6 March, 3 June 1788 and on 13 May 1791, just before it was disbanded on 27 December 1791, AN F ${ }^{12}$ 1507; Bonnassieux, Conseil de commerce (see note 3).

78 Christine MacLeod, Inventing the Industrial Revolution. The English patent system (1660180o) (Cambridge: Cambridge University Press, 1988).

79 Monopolies were suppressed in 1624, with exception of temporary invention monopolies, which were granted for fourteen years. Adam Smith, An Inquiry into the Nature and Causes of the Wealth of Nations (London: Wordsworth Classics of World Literature: 2012). 
evaluations. ${ }^{80}$ Finally, British patents were not free of charge; they thus frequently entailed a heavy financial burden on provincials and were consequently often restricted to Londoners and those with wealthy patrons or local connections. ${ }^{81}$

In spite of the dramatic change of the French institutions during the Revolution, one can observe continuity in the governance of industrial development. The promotion of industry and the shift towards a liberal system continued to be driven by the same decision-making bodies - the Comité d'agriculture et du Commerce replaced the Bureau du commerce - and by chemists and other members of the scientific community, who believed that they could be directly useful to industry, still continuing to carry out evaluations and thus taking part in the decision-making process.

\section{Acknowledgments}

I would particularly like to thank John Perkins for his precious advice and Lissa Roberts for her precise review of this essay and for her comments and suggestions which resulted in important clarifications. I would also like to thank John Christie for his bibliographical suggestions and Ernst Homburg for the data he gave me on the ceruse industry and for the constructive exchanges we had on the various meanings of the word "ceruse".

\footnotetext{
$80 \quad$ Hilaire-Pérez, “Invention,” pp. 93-144 (see note 7).

81 Such as official fees and accommodation in London (see note 78 ).
} 